\title{
JCOM \\ Citizen Science, K-12 science education and use of technology: a synthesis of empirical research
}

\section{Olia E. Tsivitanidou and Andri loannou}

\begin{abstract}
In this review, we examined the types of CS projects found in $\mathrm{K}-12$ science education facilitated by digital technologies, the learning outcomes from students' participation in these projects, and the type of digital technologies used. With the application of the study's selection criteria, 15 eligible publications were included in the review; these were indexed in three databases as well as in Google Scholar. Despite the rising popularity of CS projects, the present review revealed that there is little empirical evidence for the effects of technology-facilitated CS projects on learning outcomes when $\mathrm{K}-12$ students are involved. Yet, the review demonstrates a promising research area in science education and technology-enhanced learning.
\end{abstract}

Keywords Citizen science; Science education

DOI

https://doi.org/10.22323/2.19040901

Submitted: 8th May 2020

Accepted: 2nd July 2020

Published: 20th July 2020

Introduction

What is Citizen Science?

Citizen Science (CS) is a rapidly growing field with expanding legitimacy and involves the engagement of non-scientists in scientific research, broadening public participation in science and supporting alternative models of knowledge production. Jordan, Ballard and Phillips [2012] conceptualized CS as 'partnerships between scientists and non-scientists in which authentic data are collected, shared, and analyzed' [Jordan, Ballard and Phillips, 2012, p. 307]. The benefits of CS are assumed to extend beyond the production of important large databases [Trumbull et al., 2000], to include the development of scientific literacy. CS is recognized as an important component in the conceptualization of Open Science and Open Access approaches [see European Commission, 2016], which have gained importance as part of the rethinking of how science relates to wider societal goals. CS offers the opportunity to the wider public and especially to students to develop and/or increase an understanding of the process of science, through the engagement in authentic science projects, in contrast to traditional, tightly scripted school laboratory investigations. CS projects in several cutting-edge areas of science, are 
often initiated to address a socio-scientific issue, an immediate problem or research question. They also enable a wider discussion about their societal implications, while building capacity for communities to participate in science, scientific inquiry and policy decision-making, even though there is little detail of how projects have contributed to policy development [Hollow et al., 2015]. In addition, CS projects related to ecology have been shown to contribute towards conservation attitudes and behaviors, and towards increased appreciation and positive views towards local nature and the environment in general [Toomey and Domroese, 2013].

\section{Different types of Citizen Science projects}

Main fields of study in CS projects so far, are biology, ecology, and conservation, with the largest scientific output in ornithology, astronomy, meteorology, and microbiology. Kullenberg and Kasperowski [2016] analyzed a corpus of previous CS studies from the Web of Science (WoS), with the aim of giving a scientometric description of what the concept of CS entails. They argued that there are three main focal points of CS. The largest poll of CS projects concerned research on biology, conservation, and ecology, in which CS was mainly used as a methodology of collecting and classifying data. A second strand of research has emerged through geographic information research, where citizens participate in the collection of geographic data. Thirdly, there is a line of research relating to the social sciences and epidemiology, which examines and facilitates public participation in relation to environmental issues and health. In terms of scientific output, the largest body of articles are to be found in biology and conservation research [Kullenberg and Kasperowski, 2016].

Among those, projects may differ on the type and degree of involvement of citizens in a research project. According to Bonney et al. [2009], there are three types of projects: contributory (i.e., generally designed by scientists / researchers and for which members of the public primarily contribute data), collaborative (i.e., designed by scientists/ researchers and for which members of the public contribute data and may also contribute in refining a project design, in analyzing data and/or disseminating research findings), and the co-created projects (i.e., co-designed by scientists and members of public and for which at least some of the public participants are actively involved in most of all steps of the scientific inquiry). Co-created and collaborative CS projects can offer citizens some control over what research questions are investigated, and how data are collected. By contrast, contributory designs engage the public in collecting data, but not in the processes of research design [Dickinson et al., 2012].

\section{Science education and Citizen Science}

The importance of public understanding of science and scientific literacy for promoting a culture of scientific thinking, which involves the development of evidence-based reasoning for decision making, has been stressed by experts in the domain [Beernaert et al., 2015]. Scientific literacy empowers responsible participation in public science, but also non-science conversations, debates, and decision-making, as an active engagement of citizens in the big challenges that humanity is facing today. The idea of CS is rooted in the authentic participation in the practices of science [Buxton, 2006; NGSS Lead States, 2013; National Research 
Council (NRC), 2012] which involves community participation [Lave and Wenger, 1991] and the development of the individual's identity in science [Gee, 2003]. From this point of view, it has been reported by previous researchers that CS projects provide authentic experiences for students involved [Kountoupes and Oberhauser, 2008], leading to increased science knowledge [Brossard, Lewenstein and Bonney, 2005]. CS projects are linked to environmental education, usually including observations of climate change phenomena. Research findings have shown that such projects bare the capacity of creating awareness of climate change issues for the participants [Toomey and Domroese, 2013]. Moreover, CS projects are generally linked to authentic inquiry, which allows students to engage with phenomena, develop inquiry skills and scientific reasoning, as well as, develop positive attitudes towards science [Constantinou, Tsivitanidou and Rybska, 2018].

\section{Citizen Science in K-12}

Adult participation in CS programs may assist scientific researchers in a range of research activities [Crall et al., 2015]. Likewise, children and adolescents can contribute significantly in the research process [e.g., in data collection, see, Pocock and Evans, 2014], through appropriate guidance and learning designs that ease the enactment of CS projects. A main constraint that has been encountered in efforts to promote inquiry-based science education is the recurring tendency to seek recipe-type representations of activity structures, that can lead to classroom implementations, especially in K-12 education. Chinn and Malhotra [2002] argue that such simple inquiry tasks incorporate few, if any, features of authentic scientific inquiry. Instead, in authentic research, procedures are complex and often require considerable ingenuity in their development. That is why, CS projects can offer such authenticity in the learning experience, since, by definition, they offer the opportunity to K-12 students, to engage in real scientific processes. Especially in environmental and ecology education, in which a large number of CS projects have been implemented so far [Kullenberg and Kasperowski, 2016], current discourse in $\mathrm{K}-12$ focuses on promoting lessons in which students learn science by conducting research rather than simply reading textbooks [Bestelmeyer et al., 2015; Buchanan, Pressick-Kilborn and Maher, 2018].

\section{Technology in Citizen Science}

The advancement of digital technologies and the widespread use of the internet help to connect people easily and effectively with the scientific community and with their peers. Digital technology creates new opportunities for establishing networks and bringing together groups of people that wish to contribute to research. Over the past 20 years, several new developments in information science, especially in data informatics, graphical user interfaces, and geographic information system-based web applications, have been vital to the emergence of CS. In fact, as research and innovation are changing rapidly, digital technologies are making science and innovation more collaborative, international, and open to citizens [European Commission, 2016]. Therefore, a new range of digital tools can potentially facilitate interaction and communication between citizens and scientists [Skarlatidou et al., 2019]. Digital tools not only facilitate communication and collaboration, but also provide new means for data collection, also in large scale (e.g., via the use of smartphones with built-in sensors) [Gadermaier et al., 2018]. 
Skarlatidou et al. [2019] have already examined the application of such 'citizen science technologies' from the user experience perspective (e.g., how do volunteers interact with these technologies).

In the context of K-12 science education, Information and Communication Technologies (ICTs) and digital tools have already been used in CS projects [e.g., Merlino et al., 2015], mainly to allow the involvement of students in the scientific inquiry process. In CS projects focusing on environmental education and conservation, digital technologies can have an important contribution in several phases of the inquiry process [e.g., data sharing towards improved environmental and biodiversity activism; see, Buchanan, Pressick-Kilborn and Maher, 2018]. Also, online computer/video gaming can be used as an important tool to engage non-traditional audiences to the scientific process, including K-12 students, and thus to promoting CS participation [Buchanan, Pressick-Kilborn and Maher, 2018]. Furthermore, mobile technologies can be used to enhance and extend the learning experience beyond the classroom walls, as any student with a smartphone can potentially be a citizen scientist [Wallace and Bodzin, 2017]. Despite that, there is little empirical evidence from CS projects and learning outcomes in $\mathrm{K}-12$ science education facilitated by digital technologies.

Objectives of this review
CS projects have gained popularity and attention over the course of the past few decades. At the same time digital technologies are making science and innovation more collaborative, international, and open to citizens than ever before. Despite that, there is little empirical evidence from CS projects in K-12 science education facilitated by digital technologies. In this review, we aim to examine the types of CS projects found in K-12 science education facilitated by digital technologies, the learning outcomes from students' participation in these projects, and the type of digital technologies used. We seek to address the following research questions:

1. What are the types of CS projects in K-12 science education, facilitated by digital technologies?

2. What are the learning benefits for the students?

3. What type of digital technologies have been used?
Methods 
set to cover research published from 2009 to January 2020, covering a decade of work, which we considered adequate for providing us with the satisfactory synthesis of recent results. In addition, a search in the Google Scholar engine was conducted, using a combination of the same keyword combinations. Duplicates were removed and the remaining titles and abstracts were screened. A filtered database corpus was further assessed for eligibility, using the study selection criteria, as presented below.

\section{Selection criteria}

This pool of studies was then subjected to selection by reviewing the titles and, if necessary, the abstracts, according to the following selection criteria: (1) Research focus: the study should be reporting on the effects of CS projects in students' learning outcomes across the cognitive, affective, psychomotor and behavioral domains, in science education. (2) Empirical: the study should be providing primary data derived from quantitative, qualitative, or mixed-method design approaches. (3) Educational level: The study should be reporting research in K-12 education. (4) Use of digital technologies: The study should report on any kind of technologies used by the participants (K-12 students) for the purposes of the CS project.

\section{Coding and reliability}

We analyzed the full-text articles looking for the following elements (i.e., coding categories): place / country of implementation, educational level, type of education (formal / informal or both), domain and/or topic of CS project, research design, number of participants, pedagogy, learning outcomes (cognitive, affective, behavioral or psychomotor), and digital technology used. A total of 33.3\% of the corpus was coded independently by the two authors with a satisfactory level of agreement (Cohen's $\mathrm{k}$ ranged between .75 to .80 for the coding categories). All disagreements were discussed and resolved between the two coders allowing also for consensus on the coding process. Since the calculated Cohen's k value for reliability designated substantial agreement, the first author continued with the coding of the rest of corpus.

\section{Results}

The literature search inquiry yielded 1057 documents, while after removing duplicates, we retrieved 990 documents. The screening of the titles and abstracts limited the database corpus to 45 full texts which were further checked for eligibility, using the study selection criteria presented in the methodology. Last, after applying the selection criteria, 15 eligible peer-reviewed, journal articles remained in the review corpus.

Review manuscripts often offer critical perspectives or new theoretical orientations to the reviewed literature. Although this was the initial goal of the authors, the fact that our review only yielded 15 studies revealed an important insight, that is, the area of research in the intersection of CS, K-12 science education, and digital technologies was not a mature enough segment of the field of CS to allow a critical review of literature at this time. Yet, we proceeded with a good synthesis of 
research resulting from this wide search in the literature with the aim of offering useful direction for researchers in this area.

\section{Type of CS projects in K-12 science education, facilitated by digital technologies (RQ1)}

Despite the rising popularity of CS projects, the present review revealed that there is little empirical evidence for the effects of technology-facilitated CS projects on learning outcomes, mainly when K-12 students are involved $(n=15$; see Table 1$)$. It must be noted that quite a few manuscripts identified in the literature during the search process, reported on the outcomes and implications of CS projects with either the general population, or higher-education students, not particularly, K-12 students. In addition, several studies reported on teachers' views and their insights into how CS projects can be embedded in a classroom environment. Studies reporting educational research findings on the effects of CS programs in education, but without the use of any digital technologies by students for the purpose of the CS project, were also excluded from this review.

Among the studies, included in this review $(n=15)$, three studies were conducted in informal settings, seven studies were conducted in the context of formal education and five studies in both formal and informal scenarios. In addition, even though the study by Buchanan, Pressick-Kilborn and Maher [2018] builds on vignettes or scenarios about virtual (VR) and augmented reality (AR) and does not report on an empirical study, it has been included in this review, as, according to the authors 'we drew on data collected in research that we individually had undertaken, as well as our personal engagement and professional work in environmental, science and technology education in community, school and tertiary settings' [Buchanan, Pressick-Kilborn and Maher, 2018, p. 5], thus providing a more holistic overview of technology-facilitated CS projects in K-12 education.

About the educational level, two studies were conducted in primary education and ten studies in secondary education. The three case studies reported in the manuscript of Gaydos and Squire [2012] took place in a private K-20 school, the case studies reported in Ballard, Dixon and Harris [2017] were enacted with K-12 populations, whereas the studies of Kelemen-Finan, Scheuch and Winter [2018] and Zárybnická, Sklenicka and Tryjanowski [2017] were situated in both primary and secondary educational contexts. In terms of the country, six studies were conducted in the European Union (E.U.), six of the studies were conducted in United States of America (U.S.A.), one in Australia, one in New Zealand. The work of Koomen et al. [2018] took place in both U.S.A. and Canada.

With regards to the degree of involvement of the students, in the scientific process, the CS projects were clustered, as contributory, collaborative, or co-created, as suggested by the literature [Bonney et al., 2009]. In cases when authors did not explicitly specify the type of the CS project, we tried to infer its type from the description of the project and the methodology. Nine studies reported on contributory CS projects, four studies on collaborative and two on co-created CS projects. In the manuscript of Buchanan, Pressick-Kilborn and Maher [2018], in which five vignettes are presented, vignettes 1 and 2 were classified as contributory projects, vignette 4 as a collegial contribution project and vignette 5 is classified as collaborative CS project. 
The domains and/or topics that appeared in the CS projects that were used in the reviewed papers were: environment / environmental education (including global warming, climate changes, flora and fauna), marine environment, water conservations / stormwater research, issues associated with food, nutrition and agriculture, in particular with genetically modified organisms (GMOs), environmental sustainability, innovation in the food chain; biodiversity; and cell biology research.

\section{Learning benefits for the students (RQ2)}

Our coding concerned students' learning outcomes across four domains: cognitive, effective, psychomotor, and behavioral. A study was classified for all types of learning outcomes reported (e.g., a study reporting outcomes in two domains would be classified twice, once in each domain). All the reviewed empirical studies reported positive impacts on at least one of the four domains of learning (see Table 2).

Affective outcomes were the focus in nearly half of the reviewed studies $(n=8)$. In particular, eight studies [Buchanan, Pressick-Kilborn and Maher, 2018; Chen and Cowie, 2013; Gaydos and Squire, 2012; Herodotou et al., 2018; Kelemen-Finan, Scheuch and Winter, 2018; Musavi et al., 2018; Silva et al., 2016; Wallace and Bodzin, 2017] reported an increase in students' motivational outcomes, including an increased interest in science (see Table 2). Apart from interest in science, two studies also reported on the increase of students' interest in technology, STEM careers [Musavi et al., 2018; Wallace and Bodzin, 2017], as well as, students' interest in higher-education majors, and interest in tackling real-world data-driven issues [Musavi et al., 2018]. Two studies reported an increase in students' attitudes towards science and other fields [Kelemen-Finan, Scheuch and Winter, 2018; Wallace and Bodzin, 2017]. Furthermore, one study reported on the positive effects of CS projects on students' self-efficacy, which refers to 'the extent to which a learner has confidence in his or her ability to participate in science [... ]' [Phillips et al., 2014, p. 10] [Kelemen-Finan, Scheuch and Winter, 2018].

Moreover, a total of 10 studies reported on students' outcomes in the cognitive domain. Many of the reviewed studies $(n=8)$ reported on knowledge acquisition and conceptual understanding of science topics (see Table 2). One study reported on students' improved understanding of the Nature of Science (NOS) [e.g., Peters-Burton, 2015], and another on public understanding of science [Wallace and Bodzin, 2017]. For instance, Peters-Burton [2015] in the quasi-experimental design study, found that students generated more statements about science on the posttest than they did on the pretest [Peters-Burton, 2015]. With regards to the psychomotor domain (manual or physical skills) [e.g., Kraiger, Ford and Salas, 1993], five studies in total document positive learning outcomes in students' scientific practices and inquiry skills resulting from the participation of students in CS projects [Buchanan, Pressick-Kilborn and Maher, 2018; Koomen et al., 2018; Musavi et al., 2018]. In addition, in the study of Merlino et al. [2015] students managed to master informatics solutions skills and in the study of Zárybnická, Sklenicka and Tryjanowski [2017] the students improved their technical skills (i.e., machining and material processing, how to process project documentation). 
Table 1. Type of technology-facilitated CS projects in K-12.

\begin{tabular}{|c|c|c|c|c|c|}
\hline $\begin{array}{l}\text { Name of the } \\
\text { study }\end{array}$ & Place & $\begin{array}{c}\text { Educational } \\
\text { level }\end{array}$ & $\begin{array}{l}\text { Type of } \\
\text { education }\end{array}$ & $\begin{array}{l}\text { Type of CS } \\
\text { project }\end{array}$ & $\begin{array}{l}\text { Domain and/or } \\
\text { topic }\end{array}$ \\
\hline $\begin{array}{l}\text { 1. Ballard, } \\
\text { Dixon } \\
\text { Harris } \\
\text { [2017] }\end{array}$ & U.S.A. & K-12 & $\begin{array}{l}\text { Formal and } \\
\text { informal }\end{array}$ & Contributory & $\begin{array}{l}\text { Marine environ- } \\
\text { ment }\end{array}$ \\
\hline $\begin{array}{l}\text { 2. Buchanan, } \\
\text { Pressick- } \\
\text { Kilborn and } \\
\text { Maher [2018] }\end{array}$ & Australia & Primary & $\begin{array}{l}\text { Formal and } \\
\text { informal }\end{array}$ & $\begin{array}{l}\text { Vignettes: } \\
\text { V1-2: contrib- } \\
\text { utory; V3 n/a; } \\
\text { V4: collegial } \\
\text { contribution; } \\
\text { V5: collaborat- } \\
\text { ive }\end{array}$ & $\begin{array}{l}\text { Environmental } \\
\text { education }\end{array}$ \\
\hline $\begin{array}{l}\text { 3. Chen and } \\
\text { Cowie [2013] }\end{array}$ & $\begin{array}{l}\text { New } \\
\text { Zealand }\end{array}$ & Primary & Formal & Contributory & $\begin{array}{l}\text { Environmental } \\
\text { education (but- } \\
\text { terfly unit) }\end{array}$ \\
\hline $\begin{array}{l}\text { 4. Condon and } \\
\text { Wichowsky } \\
\text { [2018] }\end{array}$ & U.S.A. & Secondary & Formal & Collaborative & $\begin{array}{l}\text { Community and } \\
\text { family water } \\
\text { conservation }\end{array}$ \\
\hline $\begin{array}{l}\text { 5. Cornali, Po- } \\
\text { matto and Ag- } \\
\text { nella [2017] }\end{array}$ & Italy, E.U. & Secondary & $\begin{array}{l}\text { Formal and } \\
\text { informal }\end{array}$ & Collaborative & \begin{tabular}{l}
\multicolumn{2}{l}{ Socio-scientific } \\
problems of \\
great \\
impact
\end{tabular} \\
\hline $\begin{array}{l}\text { 6. Gaydos and } \\
\text { Squire [2012] }\end{array}$ & $\begin{array}{l}\text { Madison, } \\
\text { WI, } \\
\text { U.S.A. }\end{array}$ & K-20 & Formal & Contributory & Lake ecology \\
\hline $\begin{array}{l}\text { 7. Herodotou et } \\
\text { al. [2018] }\end{array}$ & U.K., E.U. & Secondary & $\begin{array}{l}\text { Formal and } \\
\text { informal }\end{array}$ & Co-created & $\begin{array}{l}\text { Several different } \\
\text { inquiry missions }\end{array}$ \\
\hline $\begin{array}{l}\text { 8. Kelemen- } \\
\text { Finan, Scheuch } \\
\text { and } \\
{[2018]}\end{array}$ & $\begin{array}{l}\text { Vienna, } \\
\text { Austria, } \\
\text { E.U. }\end{array}$ & $\begin{array}{l}\text { Primary and } \\
\text { secondary }\end{array}$ & Informal & Contributory & Biodiversity \\
\hline $\begin{array}{l}\text { 9. Koomen et al. } \\
\text { [2018] }\end{array}$ & $\begin{array}{l}\text { U.S.A. } \\
\text { and } \\
\text { Canada }\end{array}$ & Secondary & Informal & Contributory & Ecology \\
\hline $\begin{array}{l}\text { 10. Merlino et } \\
\text { al. [2015] }\end{array}$ & Italy, E.U. & Secondary & Informal & Co-created & Marine litter \\
\hline $\begin{array}{l}\text { 11. Musavi et } \\
\text { al. [2018] }\end{array}$ & U.S.A. & Secondary & $\begin{array}{l}\text { Formal and } \\
\text { informal }\end{array}$ & Collaborative & $\begin{array}{ll}\text { Stormwater } & \\
\text { research } & \\
\text { problem } & \text { of } \\
\text { stormwater } & \\
\text { pollution } & \end{array}$ \\
\hline $\begin{array}{l}12 . \quad \text { Peters- } \\
\text { Burton [2015] }\end{array}$ & $\begin{array}{l}\text { Mid- } \\
\text { Atlantic } \\
\text { region of } \\
\text { the U.S.A. }\end{array}$ & Secondary & Formal & Contributory & Ecology \\
\hline $\begin{array}{l}\text { 13. Silva et al. } \\
\text { [2016] }\end{array}$ & $\begin{array}{l}\text { Spain, } \\
\text { Portugal, } \\
\text { E.U. }\end{array}$ & Secondary & Formal & Collaborative & $\begin{array}{l}\text { Molecular bio- } \\
\text { logy: Cell Spot- } \\
\text { ting project }\end{array}$ \\
\hline $\begin{array}{l}\text { 14. Wallace and } \\
\text { Bodzin [2017] }\end{array}$ & $\begin{array}{l}\text { Eastern } \\
\text { United } \\
\text { States }\end{array}$ & Secondary & Informal & Contributory & $\begin{array}{l}\text { Global warm- } \\
\text { ing and climate } \\
\text { change }\end{array}$ \\
\hline $\begin{array}{l}\text { 15. Zárybnická, } \\
\text { Sklenicka and } \\
\text { Tryjanowski } \\
\text { [2017] }\end{array}$ & $\begin{array}{l}\text { Czech } \\
\text { Republic, } \\
\text { E.U. }\end{array}$ & $\begin{array}{l}\text { Primary and } \\
\text { secondary }\end{array}$ & Formal & Contributory & $\begin{array}{l}\text { Wildlife and } \\
\text { nature conserva- } \\
\text { tion }\end{array}$ \\
\hline
\end{tabular}


Last, five studies reported positive behavioral learning outcomes, and specifically an increase in students' engagement in the scientific process [Chen and Cowie, 2013; Condon and Wichowsky, 2018; Herodotou et al., 2018] whilst, one study reported on the benefits that may arise in students' social skills [Cornali, Pomatto and Agnella, 2017] and one study reported on a positive intended behavior of students' towards biodiversity [Kelemen-Finan, Scheuch and Winter, 2018].

Table 2: Learning benefits for the students (RQ2).

\begin{tabular}{|c|c|c|c|}
\hline Name of the study & Research design & $\begin{array}{l}\text { Number of } \\
\text { participants }\end{array}$ & $\begin{array}{l}\text { Learning (cognitive, } \\
\text { affective, psychomotor, } \\
\text { behavioral) }\end{array}$ \\
\hline $\begin{array}{l}\text { 1. Ballard, Dixon } \\
\text { and Harris [2017] }\end{array}$ & 3 Case studies & $\begin{array}{l}25 \text { students and } \\
\text { teachers (do not } \\
\text { clarify) }\end{array}$ & $\begin{array}{l}\text { Cognitive: understanding } \\
\text { environmental science con- } \\
\text { tent and scientific inquiry } \\
\text { (emphasis on environ- } \\
\text { mental science agency) }\end{array}$ \\
\hline $\begin{array}{l}2 . \quad \text { Buchanan, } \\
\text { Pressick-Kilborn } \\
\text { and Maher [2018] }\end{array}$ & Qualitative & Not applicable & $\begin{array}{l}\text { Affective: interest in science; } \\
\text { Psychomotor: scientific (en- } \\
\text { vironmental) practices }\end{array}$ \\
\hline $\begin{array}{l}\text { 3. Chen and Cowie } \\
\text { [2013] }\end{array}$ & Case study & $\begin{array}{l}2 \text { teachers, no of } \\
\text { students not spe- } \\
\text { cified }\end{array}$ & $\begin{array}{l}\text { Cognitive: conceptual un- } \\
\text { derstanding; Affective: in- } \\
\text { terest in science; Behavioral: } \\
\text { engagement in science }\end{array}$ \\
\hline $\begin{array}{l}\text { 4. Condon and } \\
\text { Wichowsky [2018] }\end{array}$ & $\begin{array}{l}\text { Quasi-experimental } \\
\text { design: Pre-test - } \\
\text { Post-test design }\end{array}$ & $\begin{array}{l}15 \text { science teachers, } \\
551 \text { students }\end{array}$ & $\begin{array}{l}\text { Behavioral: student engage- } \\
\text { ment in science and civics }\end{array}$ \\
\hline $\begin{array}{l}\text { 5. Cornali, Po- } \\
\text { matto and Agnella } \\
{[2017]}\end{array}$ & $\begin{array}{l}\text { Quasi-experimental } \\
\text { design: Pre-test - } \\
\text { Post-test design }\end{array}$ & $\begin{array}{l}\text { over } 4,200 \text { stu- } \\
\text { dents, } 160 \text { teachers }\end{array}$ & $\begin{array}{l}\text { Cognitive: understand- } \\
\text { ing of socio-scientific } \\
\text { issues; awareness of the } \\
\text { importance of discussion; } \\
\text { Behavioral: social skills } \\
\text { (interactions with peers) }\end{array}$ \\
\hline $\begin{array}{l}\text { 6. Gaydos and } \\
\text { Squire [2012] }\end{array}$ & $\begin{array}{l}\text { Design-based re- } \\
\text { search: Multiple } \\
\text { users' studies (pilot } \\
\text { expert-novice study); } \\
\text { Case study (classroom } \\
\text { study context) }\end{array}$ & $\begin{array}{l}3 \quad \text { experts, } 21 \\
\text { middle-school } \\
\text { students }\end{array}$ & $\begin{array}{l}\text { Cognitive: conceptual un- } \\
\text { derstanding; Affective: in- } \\
\text { terest in science, citizen sci- } \\
\text { entist identity }\end{array}$ \\
\hline $\begin{array}{l}\text { 7. Herodotou et al. } \\
\text { [2018] }\end{array}$ & $\begin{array}{l}\text { Design-based re- } \\
\text { search: Multiple } \\
\text { users' studies (expert } \\
\text { review combined } \\
\text { with user experience } \\
\text { studies) }\end{array}$ & $\begin{array}{l}3 \text { design experi- } \\
\text { ments; } 96 \text { students } \\
\text { (aged 16-18); } 43 \\
\text { students (aged } \\
\text { 16-18); } 101 \text { adults }\end{array}$ & $\begin{array}{l}\text { Affective: interest and mo- } \\
\text { tivation in CS projects; Be- } \\
\text { havioral: engagement }\end{array}$ \\
\hline $\begin{array}{l}\text { 8. Kelemen-Finan, } \\
\text { Scheuch and } \\
\text { Winter [2018] }\end{array}$ & $\begin{array}{l}\text { Quasi-experimental } \\
\text { design: Pre-test - } \\
\text { Post-test design }\end{array}$ & $\begin{array}{l}428 \text { students (aged } \\
8-18)\end{array}$ & $\begin{array}{l}\text { Affective: interest, self- } \\
\text { efficacy/mastery, motiv- } \\
\text { ation, attitudes towards } \\
\text { biodiversity; Behavioral: } \\
\text { positive intended behavior }\end{array}$ \\
\hline $\begin{array}{l}\text { 9. Koomen et al. } \\
\text { [2018] }\end{array}$ & Case study & 5 students & $\begin{array}{l}\text { Psychomotor: authentic } \\
\text { participation in science, } \\
\text { scientific practices }\end{array}$ \\
\hline
\end{tabular}

Continued on the next page. 
Table 2: Continued from the previous page.

\begin{tabular}{|c|c|c|c|}
\hline Name of the study & Research design & $\begin{array}{l}\text { Number of } \\
\text { participants }\end{array}$ & $\begin{array}{l}\text { Learning (cognitive, } \\
\text { affective, psychomotor, } \\
\text { behavioral) }\end{array}$ \\
\hline $\begin{array}{l}\text { 10. Merlino et al. } \\
\text { [2015] }\end{array}$ & Two-group design & 18 students & $\begin{array}{l}\text { Cognitive: conceptual un- } \\
\text { derstanding (socio-scientific } \\
\text { issues); Psychomotor: in- } \\
\text { formatics solutions mastery } \\
\text { skills }\end{array}$ \\
\hline $\begin{array}{l}\text { 11. Musavi et al. } \\
\text { [2018] }\end{array}$ & $\begin{array}{l}\text { Quasi-experimental } \\
\text { design: Interrupted } \\
\text { Time Series Design } \\
\text { (four pre- and post- } \\
\text { program surveys) }\end{array}$ & $\begin{array}{l}220 \text { students, } 25 \\
\text { teachers }\end{array}$ & $\begin{array}{l}\text { Cognitive: knowledge ac- } \\
\text { quisition; Affective: interest } \\
\text { in STEM fields, in higher } \\
\text { education majors, and fu- } \\
\text { ture careers; interest in tack- } \\
\text { ling real-world data-driven } \\
\text { issues; level of confidence } \\
\text { and comfort in taking STEM } \\
\text { courses; Psychomotor: sci- } \\
\text { entific practices (e.g., col- } \\
\text { lecting water data via probe) }\end{array}$ \\
\hline $\begin{array}{l}\text { 12. Peters-Burton } \\
\text { [2015] }\end{array}$ & $\begin{array}{l}\text { Quasi-experimental } \\
\text { design: Pre-test - } \\
\text { Post-test design }\end{array}$ & $\begin{array}{l}40 \text { science students } \\
\text { (aged 12-14) }\end{array}$ & $\begin{array}{l}\text { Cognitive: understand- } \\
\text { ing of science as exper- } \\
\text { imentation; conceptual } \\
\text { understanding of the NOS }\end{array}$ \\
\hline $\begin{array}{l}\text { 13. Silva et al. } \\
\text { [2016] }\end{array}$ & Feasibility study & $\begin{array}{l}\text { hundreds of stu- } \\
\text { dents (aged 15-18) }\end{array}$ & $\begin{array}{l}\text { Cognitive: knowledge ac- } \\
\text { quisition; Affective: motiva- } \\
\text { tion }\end{array}$ \\
\hline $\begin{array}{l}\text { 14. Wallace and } \\
\text { Bodzin [2017] }\end{array}$ & $\begin{array}{l}\text { Quasi-experimental } \\
\text { design: Pre-test - } \\
\text { Post-test } \text { design } \\
(\mathrm{n}=39, \quad \text { participated } \\
\text { in CS project; } \mathrm{n}=39, \\
\text { received 'traditional' } \\
\text { instruction) }\end{array}$ & $\begin{array}{l}\mathrm{n}=789^{\text {th }} \text {-grade stu- } \\
\text { dents (aged 14-15) }\end{array}$ & $\begin{array}{l}\text { Cognitive: public under- } \\
\text { standing of science; Affect- } \\
\text { ive: attitudes toward mo- } \\
\text { bile learning or learning sci- } \\
\text { ence and technology; In- } \\
\text { terest in science and techno- } \\
\text { logy and STEM careers, and } \\
\text { perceived identity regard- } \\
\text { ing scientific citizenship }\end{array}$ \\
\hline $\begin{array}{l}\text { 15. Zárybnická, } \\
\text { Sklenicka and Try- } \\
\text { janowski [2017] }\end{array}$ & $\begin{array}{l}\text { Quasi-experimental } \\
\text { design: Pre-test - } \\
\text { Post-test design }\end{array}$ & 53 students & $\begin{array}{l}\text { Cognitive: conceptual un- } \\
\text { derstanding; Psychomotor: } \\
\text { technical skills }\end{array}$ \\
\hline
\end{tabular}

\section{Digital technologies used in CS projects (RQ3)}

Among the 15 manuscripts reviewed, the study of Peters-Burton [2015] reported on the use of probes by students for data collection purposes in independent research projects (topic of ecology), Koomen et al. [2018] reported on the use of project boards for data collection and analysis in ecology CS. The rest of the studies made more explicit use of digital technologies such as mobile applications (4 studies), web-based applications/tools (4 studies), online/web platforms (3 studies), games (2 studies), VR and AR (1 study), sensors and 3D printing (1 study), and virtual excursion rooms (1 study). The findings are summarized in Table 3 and discussed further below. 
Table 3: Technologies used in CS projects (RQ3).

\begin{tabular}{|c|c|c|c|}
\hline Name of the study & $\begin{array}{c}\text { Type of } \\
\text { technology }\end{array}$ & $\begin{array}{c}\text { Name of } \\
\text { technological tool }\end{array}$ & Features/Use \\
\hline $\begin{array}{l}\text { 1. Ballard, Dixon } \\
\text { and Harris [2017] }\end{array}$ & $\begin{array}{l}\text { Website and } \\
\text { blog }\end{array}$ & LiMPETS & $\begin{array}{l}\text { Students sharing their data on the } \\
\text { LiMPETS Website and disseminating } \\
\text { their findings in an online blog. }\end{array}$ \\
\hline $\begin{array}{l}2 . \quad \text { Buchanan, } \\
\text { Pressick-Kilborn } \\
\text { and Maher [2018] }\end{array}$ & $\begin{array}{l}\text { Mobile app, } \\
\text { VR, AR }\end{array}$ & $\begin{array}{l}\text { QuestaGame; } \\
\text { FrogID App }\end{array}$ & $\begin{array}{l}\text { Gamification elements in a mobile } \\
\text { app potential to raise environmental } \\
\text { awareness and engage users in an en- } \\
\text { vironmental initiative. }\end{array}$ \\
\hline $\begin{array}{l}\text { 3. Chen and Cowie } \\
\text { [2013] }\end{array}$ & Webpage & $\begin{array}{l}\text { Science Learning } \\
\text { Hub (SLH) }\end{array}$ & $\begin{array}{l}\text { The webpage provides guidance to } \\
\text { teachers and allows students to pub- } \\
\text { lish their data. }\end{array}$ \\
\hline $\begin{array}{l}\text { 4. Condon and } \\
\text { Wichowsky [2018] }\end{array}$ & $\begin{array}{l}\text { Web-based } \\
\text { application }\end{array}$ & - & $\begin{array}{l}\text { The app allows collaboration among } \\
\text { students and use of crowdsourced } \\
\text { data, for solving an environmental } \\
\text { problem. }\end{array}$ \\
\hline $\begin{array}{l}\text { 5. Cornali, Po- } \\
\text { matto and Agnella } \\
\text { [2017] }\end{array}$ & $\begin{array}{l}\text { Web plat- } \\
\text { form }\end{array}$ & Scienza Attiva & $\begin{array}{l}\text { A web platform for increasing interac- } \\
\text { tion among users. The website is used } \\
\text { for sharing knowledge and for com- } \\
\text { munication purposes among students } \\
\text { and experts. }\end{array}$ \\
\hline $\begin{array}{l}\text { 6. Gaydos and } \\
\text { Squire [2012] }\end{array}$ & $\begin{array}{l}\text { Educational } \\
\text { digital game }\end{array}$ & Citizen Science & $\begin{array}{l}\text { The game's narrative parts situated } \\
\text { the problem; then the students con- } \\
\text { front challenges, gather data, argue } \\
\text { with characters, observe results, and } \\
\text { change the world. }\end{array}$ \\
\hline $\begin{array}{l}\text { 7. Herodotou et al. } \\
\text { [2018] }\end{array}$ & $\begin{array}{l}\text { A set of } \\
\text { web-based } \\
\text { and mobile } \\
\text { tools }\end{array}$ & $\begin{array}{l}\text { nQuire toolkit } \\
\text { and Sense-it ap- } \\
\text { plication }\end{array}$ & $\begin{array}{l}\text { A set of interaction design principles } \\
\text { that aim to guide the development of } \\
\text { online, learning-centered, CS projects. }\end{array}$ \\
\hline $\begin{array}{l}\text { 8. Kelemen-Finan, } \\
\text { Scheuch and } \\
\text { Winter [2018] }\end{array}$ & $\begin{array}{l}\text { Custom- } \\
\text { made } \\
\text { database } \\
\text { application }\end{array}$ & - & $\begin{array}{l}\text { Custom-made database application } \\
\text { for data collection purposes. }\end{array}$ \\
\hline $\begin{array}{l}\text { 9. Koomen et al. } \\
\text { [2018] }\end{array}$ & $\begin{array}{l}\text { Project } \\
\text { boards }\end{array}$ & - & $\begin{array}{l}\text { Project boards were used by students } \\
\text { for data collection and analysis. }\end{array}$ \\
\hline $\begin{array}{l}\text { 10. Merlino et al. } \\
\text { [2015] }\end{array}$ & $\begin{array}{l}\text { Mobile app } \\
\text { (Android) }\end{array}$ & SeaCleaner App & $\begin{array}{l}\text { Data Collection } \\
\text { SeaCleaner App, } \\
\text { students. }\end{array}$ \\
\hline $\begin{array}{l}\text { 11. Musavi et al. } \\
\text { [2018] }\end{array}$ & $\begin{array}{l}\text { Sensors and } \\
3 \mathrm{D} \text { printing } \\
\text { tools }\end{array}$ & $\begin{array}{l}\text { Pasco sensors, } \\
\text { Tuva Labs, Excel, } \\
\text { and Google Earth }\end{array}$ & $\begin{array}{l}\text { Sensors were used for collecting envir- } \\
\text { onmental data (e.g., pH, conductivity, } \\
\text { temperature, and flow rate). }\end{array}$ \\
\hline $\begin{array}{l}\text { 12. Peters-Burton } \\
\text { [2015] }\end{array}$ & Probes & - & $\begin{array}{l}\text { Using probes to collect data in the in- } \\
\text { dependent research projects. }\end{array}$ \\
\hline $\begin{array}{l}\text { 13. Silva et al. } \\
\text { [2016] }\end{array}$ & $\begin{array}{l}\text { Web-based } \\
\text { application }\end{array}$ & $\begin{array}{l}\text { Cell Spotting app; } \\
\text { Virtual Science } \\
\text { Hub 'ViSH' }\end{array}$ & $\begin{array}{l}\text { A web app that allows users to observe } \\
\text { and analyze thousands of images of } \\
\text { cancer cells under the treatment of } \\
\text { potential drugs obtained by fluores- } \\
\text { cence microscopy over time. Con- } \\
\text { tains a selection of e-Infrastructures } \\
\text { and science-teaching related material. }\end{array}$ \\
\hline
\end{tabular}

Continued on the next page. 
Table 3: Continued from the previous page.

\begin{tabular}{|c|c|c|c|}
\hline Name of the study & $\begin{array}{c}\text { Type of } \\
\text { technology }\end{array}$ & $\begin{array}{c}\text { Name of } \\
\text { technological tool }\end{array}$ & Features/Use \\
\hline $\begin{array}{l}\text { 14. Wallace and } \\
\text { Bodzin [2017] }\end{array}$ & Mobile apps & $\begin{array}{l}\text { Leafsnap app, } \\
\text { Where Am I At } \\
\text { app; Project Bud- } \\
\text { burst observation } \\
\text { report }\end{array}$ & $\begin{array}{l}\text { Leafsnap app: used to identify tree } \\
\text { species; 'Where Am I At' app: to cap- } \\
\text { ture sample locations. Project Bud- } \\
\text { burst observation report: to record all } \\
\text { the data, camera apps to take photos } \\
\text { of the local environment and collected } \\
\text { leaves. }\end{array}$ \\
\hline $\begin{array}{l}\text { 15. Zárybnická, } \\
\text { Sklenicka and Try- } \\
\text { janowski [2017] }\end{array}$ & $\begin{array}{l}\text { Computer } \\
\text { and sensors }\end{array}$ & $\begin{array}{l}\text { Smart Nest Box } \\
\text { (SNBox) }\end{array}$ & $\begin{array}{l}\text { A bird box equipped with a computer, } \\
\text { one or two cameras, an optical sensor } \\
\text { that senses activity, temperature and } \\
\text { light sensors, and a microphone. }\end{array}$ \\
\hline
\end{tabular}

Discussion

In this review we sought to examine the types of CS projects found in $\mathrm{K}-12$ science education facilitated by digital technologies, the learning outcomes resulted from students' participation in these projects, and the type of digital technologies used. Studies were identified across different regions, in both formal and informal educational settings in K-12 levels. The CS projects were clustered, as contributory, collaborative, or co-created, as suggested by the literature [Bonney et al., 2009]. In addition, a new category of CS projects emerged, the collegial contributions project, proposed by Buchanan, Pressick-Kilborn and Maher [2018], which relates to the role of the citizens in the scientific process.

In relation to the domains and/or topics that appeared in the CS projects, the largest poll of CS projects concerned research on biology, conservation, and ecology, as expected, in which CS was mainly used as a methodology for collecting and classifying data [Kullenberg and Kasperowski, 2016]. Also, the research topics being addressed in the CS projects concern, in most of the cases, socio-scientific issues, of social impact.

CS projects enacted in K-12 education bare learning benefits for the students, across four domains: cognitive (intellectual aspect of learning) [e.g., Bloom, 1956; Gagné, 1977], affective (relating to interest, attitude and values) [Krathwohl et al., 2002], psychomotor (manual or physical skills) [e.g., Kraiger, Ford and Salas, 1993], and behavioral domains (social skills and interactions) [e.g., Phillips et al., 2014]. For primary and secondary-school students, the participation in technology-facilitated CS projects in science education provides them with an opportunity to develop their scientific skills and competences and to master technological solutions (i.e. via tools and app design and development). CS programs provide real-life science scenarios, in which the students can contribute to the scientific community [e.g., Peters-Burton, 2015] and thus, experience an authentic inquiry-learning process. In authentic inquiry, students have better opportunities to engage with phenomena, develop inquiry skills and scientific reasoning, understand the meaning of doing and talking science, develop epistemological awareness of the NOS and develop positive attitudes towards science [Constantinou, Tsivitanidou and Rybska, 2018]. In the studies reported in this review, students reported higher motivational beliefs regarding science, and they showed higher levels of achievement post interventions in CS programs, as compared to control groups following conventional science courses inside the class [Wallace and Bodzin, 2017]. Students' 
motivational beliefs influence content knowledge and outcome expectations, which in turn can affect their STEM career goals [European Commission, 2016; Rocard et al., 2007]. These results have implications for incorporating authentic fieldwork within a formal school structure as an effective method for supporting students' science learning, for promoting student achievement and STEM career motivation [Wallace and Bodzin, 2017] and towards fostering social skills and competences necessary for citizenship education [Cornali, Pomatto and Agnella, 2017].

Moreover, a variety of digital technologies (e.g., mobile applications, web-based platforms) have been used in the CS projects reported in the reviewed papers, linked to students' learning benefits. These are discussed in detail below.

Mobile applications. Mobile technologies can facilitate the implementation of CS tasks, e.g., data collection [Devisch and Veestraeten, 2013]. The use mobile technologies as part of an authentic practice may serve as an important bridge between formal education and real-life contexts. In this respect, mobile learning has the potential to create meaningful, situated [Huang et al., 2016] and authentic learning in various contexts [e.g., De Pietro, 2013]. It provides the opportunity for learners to extend their learning experiences outside the classroom and enables the acquisition of knowledge and skills, as the learners perform activities in real and interactive situations. In other words, the use of mobile technologies might enable learners to meaningfully interpret the knowledge and skills acquired during such a process and expand their self-interest [Brown, Collins and Duguid, 1989]. For instance, Silva et al. [2016] in their study, used the CS application 'Cell Spotting', an application for image data analysis, that hundreds of secondary students used; the app allowed them to observe and analyze thousands of images of cancer cells under the treatment of potential drugs obtained by fluorescence microscopy over time. As reported by the authors [Silva et al., 2016], students were motivated to participate in the CS project, while acknowledging the value of contributing to an important project. However, those results must be interpreted with caution, considering that the students participated in the CS project in the context of their formal education and not on a voluntary basis.

In the Merlino et al. [2015] study, a co-design approach with the active involvement of the students was followed, for the design and development of a data collection protocol in the form of an Android mobile application, the so-called SeaCleaner App. The mobile application was used for data collection purposes, in the context of the CS project described in the paper of Merlino et al. [2015]. Also, Wallace and Bodzin [2017] presented the so-called 'Mobile Learning and Authentic Practice' approach (MobiLAP) as a promising approach that integrates CS, mobile learning, and authentic practice. MobiLAP builds on the work of Gaydos and Squire [2012] by integrating mobile learning with authentic CS experiences to foster scientific citizenship in participants. This approach is especially suitable for informal educational settings. MobiLaP had a significant impact on students' attitudes toward citizen science identity and careers in STEM areas. Finally, Buchanan, Pressick-Kilborn and Maher [2018] provide comprehensive examples of the exploitation of mobile apps in CS projects (i.e., QuestaGame; FrogID App), while Gaydos and Squire [2012] present a mobile app game (i.e., so-called 'Citizen Science') experience and impact on students' identity as citizen scientists. Those mobile app games are further discussed below. 
Overall, even though the use of mobile applications, as part of a CS project, bares several benefits to students' learning, few constraints of mobile learning should be also encountered, such as, possible technical barriers (i.e., connection issues, inconsistent platforms), and possibility for negative learning effects (i.e., distraction) [Orr, 2010]. In addition, meaningfulness of mobile learning is subjected to conditions (e.g., way of integration, teacher pedagogical strategies, and application/software appropriateness) [Nikolopoulou, 2020].

Gaming and digital gaming. Gaming, including digital gaming, has been shown to add a stratum of purpose to a sustainability education goal. As already mentioned above, Gaydos and Squire [2012] present an educational digital game, so-called 'Citizen science', a game for identification with scientific citizenship. The game aims to help learners develop identities as citizen scientists within the domain of lake ecology. Its core mission is for students to solve problems of pollution of a virtual lake system. The core game mechanic of the CS game involves confronting challenge(s), gathering data, arguing with characters, observing results, and changing the world. Underlying Citizen Science is a social theory of learning, while the methodological approach is design-based research. The players must gather data from around Lake Mendota and connect it to data generated from a realistic simulation to 'convince legislators to promote the planting of agricultural buffer strips along waterways, and the setting of limits to the amounts of agricultural run-off farms can produce' (p. 827). The goal of CS is to give to the players experiences of resolving real-life ecological issues, conduct a scientific inquiry to address these issues, and act in the (virtual) world to affect change. In this sense, the game simulates a scenario in which the students contribute towards the solution of an environmental problem, following a CS approach; positive learning outcomes relate to an increased interest, knowledge, and values toward becoming a citizen scientist, hence, supporting the argument of mobile learning potential. It has to be noted that, even though the intervention reported by Gaydos and Squire [2012] was not completely authentic, one could argue that since the learning simulation did have an authentic, real-life context, modeling a real-life problem, the student learning activity could be considered to involve authentic science practices.

Moreover, Buchanan, Pressick-Kilborn and Maher [2018] provide a narrative description and analysis of a vignette on an educational experience with the mobile app QuestaGame (https: / / questagame.com/btn-video/), which can be used in primary school-based environmental education. The QuestaGame, which is an application available on mobile devices, comprises an interesting way for users to share their wildlife spotting with others, as well as, finding out more about what species are being observed nearby. Among the gamification elements embedded in the game, is the fact that, the more information users shared by adding field notes to their sightings and making correct identifications, the more 'gold' they collected, while receiving rewards within the game. Also, collaborative, and competitive features were implanted in the overall scenario (e.g., in-built collaborative features include the clan membership and the possibility of creating quests for other QuestaGamers). Another data gathering tool, reported in the manuscript of Buchanan, Pressick-Kilborn and Maher [2018], is the free app, FrogID, supported by a website that is designed as an engagement platform (https:/ / www.frogid.net.au/) [Buchanan, Pressick-Kilborn and Maher, 2018]. FrogID App is a mobile app that enables citizen scientists to use the microphone on 
a smartphone to record a frog's distinctive call, which is then uploaded alongside location data. Calls are then identified by experts and added to a bioacoustic database, incorporating other information about each species.

Web-based/online platforms. Herodotou et al. [2018] followed a repetitious pedagogy-led design process and evaluation of the nQuire toolkit, that is comprised by a set of web-based and mobile tools scaffolding the creation of online CS investigations. The toolkit is connected to a sensor-based application, so-called 'Sense-it', that is linked to the platform to support data collection by the students while using their mobile devices. Silva et al. [2016] report the use of a virtual excursion room, where schools were able to remotely experience the work at the cell laboratory, via the GLOBAL Virtual Science Hub 'ViSH', which contains a selection of e-Infrastructures and educational material accessible to both teachers and scientists for establishing collaborations. In addition, the teachers were provided with online platforms which encompassed teaching activity packages published by Casa das Ciências - http:/ / www.casadasciencias.org. [Monteiro, Silva, Brito et al., 2014] and Science in School - http:/ / www.scienceinschool.org [Monteiro, Silva and Carrodeguas Villar, 2015]. Those packages aimed to promote inspiring science teaching, by facilitating the collaboration between teachers and scientists through joint activities. Moreover, Cornali, Pomatto and Agnella [2017] used a web-platform for the purposes of the Scienza Attiva CS project. The web platform supported the interaction and communication among students and experts and provided space for sharing knowledge. Condon and Wichowsky [2018], in their study, used STEMhero, a curriculum designed for middle-school science classrooms, that uses a web-based application to track and analyze utility consumption (i.e., water, gas, and electric meters). This web app facilitates the integration of science and civics lessons on natural resource management. It is designed to use real-world sustainability challenges and authentic inquiry to inspire student engagement in STEM.

Augmented reality. Buchanan, Pressick-Kilborn and Maher [2018] in one of the vignettes that they have developed, propose the use of AR for CS, which can be adopted in project-based learning approaches for supporting associated learning. Buchanan, Pressick-Kilborn and Maher [2018] commented on several features of an AR app (e.g., scanning flora and fauna with the app, which super-imposes, the flowers of plants currently not in bloom). Users' engagement with the topic of CS interest could also be supported by features, such as the incorporation of a treasure hunt that would be undertaken via the AR feature. AR can be framed within game-based learning and allow increased interactivity among users. Linked to the latter, the AR app would allow participants to connect to each other's devices so that they share information for CS purposes. Overall, AR technologies seem to offer the potential to engage students and citizens generally in a real-world experience supported by a project-based learning approach. Within such an approach, teachers may adopt the role of the 'facilitator', just like in inquiry-based learning, offering support and scaffolds when needed. Also, with AR, a student can experience flora and fauna in the natural setting that may be absent at that time; for example, a nocturnal animal or one that is seasonally present. Such apps may provide data analytics to the teacher to support the assessment of student learning. Students also can analyze data user engagement. The application allows students' interaction, but also real-time updates for parents on their children's' learning. 
However, few constraints should be thought through, for instance, resourcing and availability. First, a wide variety of resources is needed, which can be difficult for schools to resource. Therefore, it might become problematic, for teachers, to provide appropriate and timely feedback, to facilitate individual and cooperative learning, and to engage students in meaningful assessment and self-reflection [Barron and Darling-Hammond, 2008]. Second, emerging technologies, e.g., AR, might not be available at schools. It will take some time before such types of technology becomes mainstream and widespread.

Virtual reality (VR). Buchanan, Pressick-Kilborn and Maher [2018], in one of their vignettes, suggest the design and development of a VR app that allows primary-school students to construct different options of walking tracks in a nature reserve, and then assess the impact on a local endangered native lizard population. The students collaborate with the National Parks and Wildlife (NPAW) Department staff to plan three scenarios with minimal impact on the lizards and trial the three scenarios themselves and collect associated data. The NPAW staff then constructs the suggested path based on students' data. With the use of the VR, the students are invited, virtually and through on-site visits, to help monitor the use of the new path and the impact it is having on the local lizard population, through the continued collection and analysis of data in conjunction with NPAW staff. This type of technology offers the opportunity to industry, the government, and the schools to collaborate. Primary school students can undertake real-life scientific investigations, collect, and analyze and share their outcomes with the community. The development of organization and communication skills of students is also prompted. In this way, the students, as citizen scientists, contribute towards the creation of large databases. However, the collection of data requires careful management. Also, to ensure the reliability and validity of data collected by primary-school students, both teachers and students involved in the CS project need training in appropriate data gathering and interpretation.

Sensors and 3D printing tools. Students in Musavi et al. [2018] participated the Stormcwater Management and Research Team (SMART) CS program (U.S.A.) and used off-the-shelf Pasco sensors to collect environmental data [Musavi et al., 2018]. Data analysis was done later using data visualization and analysis tools, including but not limited to Tuva Labs, Excel, and Google Earth. Students were introduced to aspects of sensor design, looking specifically at the design of off-the-shelf sensors, but also to 3D printing for designing boxes that house the sensors. Moreover, in the study of Zárybnická, Sklenicka and Tryjanowski [2017] a SNBox (bird box) was used by the participants, including students, in their own schoolyard, which allowed a remote data (on the birds' behavior) transmission to the researchers. Data were transmitted by the user's local Internet network to the central server. Access to this data was given to students, as well, allotting them to further analyze it and conduct inquiry investigations.

The term Citizen Science (CS) has gained increased popularity and attention over the course of the past few decades. At the same time digital technologies are making science and innovation more collaborative, international, and open to citizens than ever before. In this review we aim to examine the types of CS projects found in K-12 science education facilitated by digital technologies, the learning 
outcomes from students' participation in these projects, and the type of digital technologies used. Our synthesis of research resulting, upon a wide search in the literature, offers useful insights in this area. Even though research in the intersection of CS, K-12 science education and technology is still very limited, some evidence does exist, demonstrating positive learning outcomes for the students participating in technology-facilitated CS projects.

With regards to the types of digital technologies used in K-12 science education CS projects, it has been acknowledged that potential benefits on students' learning may arise, as they offer new forms of inquiry, communication, collaboration, and identity work with positive cognitive, social, and emotional impacts [see: Buchanan, Pressick-Kilborn and Maher, 2018; Greenhow and Lewin, 2016]. Technological tools allow the connection to (big) data, as well as, the opportunity to contribute to it, connection to supplementary 'augmented' information and experiences, connection to experts, and to other learners, communication and collaboration among learners and scientists. ICT in combination with a CS approach offer an effective opportunity for inspiring students to have fun while learning to act like scientists. CS applications may also contribute to establishing new machine learning techniques. For example, in the study of Silva et al. [2016] the CS application Cell Spotting allowed citizens' participation in the analysis of large data sets; the compiled results enabled the creation of a large training set that can be used for machine learning techniques, allowing for the automatic analysis of future cancer cells images [Silva et al., 2016].

The small corpus of empirical work in the interception of CS, K-12 science education and technology revealed an important insight, that is, the area of research is not a mature enough segment of the field of CS to allow a critical review of literature at this time. In addition, not all of the reviewed studies supported their findings with statistically significant measures to authenticate results; subsequently, even though numerous benefits have been reported to arise in terms of learning progression due to the CS projects implementation in K-12 education, this is an area that needs further exploration. Yet, our synthesis of the work based on 15 reviewed papers aims to guide further research in the field, acknowledging the positive outcomes of CS projects in K-12, as well as, the potential of technology to support such projects. Concluding, CS can play an important role in $\mathrm{K}-12$ science education. The use of technology in CS K-12 projects is still in its infancy; hence this is a promising research area in science education and technology-enhanced learning.

References

Ballard, H. L., Dixon, C. G. H. and Harris, E. M. (2017). 'Youth-focused citizen science: examining the role of environmental science learning and agency for conservation'. Biological Conservation 208, pp. 65-75. https://doi.org/10.1016/j.biocon.2016.05.024.

Barron, B. and Darling-Hammond, L. (2008). ‘Teaching for meaningful learning: a review of research on inquiry-based and cooperative learning'. In: Powerful learning. What we know about teaching for understanding. Ed. by L. Darling-Hammond, B. Barron, P. D. Pearson, A. H. Schoenfeld, E. K. Stage, T. D. Zimmermann, G. N. Cervetti and J. Tilson. San Francisco, CA, U.S.A.: Jossey-Bass, pp. 11-70. 
Beernaert, Y., Constantinou, P. C., Deca, L., Grangeat, M., Karikorpi, M., Lazoudis, A., Casulleras, R. P. and Welzel-Breuer, M. (2015). Science education for responsible citizenship. EU 26893. European Commission. Luxembourg: Publications Office of the European Union. https://doi .org/10.2777/12626.

Bestelmeyer, S. V., Elser, M. M., Spellman, K. V., Sparrow, E. B., Haan-Amato, S. S. and Keener, A. (2015). 'Collaboration, interdisciplinary thinking, and communication: new approaches to K-12 ecology education'. Frontiers in Ecology and the Environment 13 (1), pp. 37-43. https://doi.org/10.1890/140130.

Bloom, B. (1956). Taxonomy of educational objectives - the cognitive domain. New York, NY, U.S.A.: Donald McKay.

Bonney, R., Cooper, C. B., Dickinson, J., Kelling, S., Phillips, T., Rosenberg, K. V. and Shirk, J. (2009). 'Citizen Science: a Developing Tool for Expanding Science Knowledge and Scientific Literacy'. BioScience 59 (11), pp. 977-984. https://doi.org/10.1525/bio.2009.59.11.9.

Brossard, D., Lewenstein, B. and Bonney, R. (2005). 'Scientific knowledge and attitude change: The impact of a citizen science project'. International Journal of Science Education 27 (9), pp. 1099-1121. https://doi.org/10.1080/09500690500069483.

Brown, J. S., Collins, A. and Duguid, P. (1989). 'Situated cognition and the culture of learning'. Educational Researcher 18 (1), pp. 32-42. https://doi.org/10.3102/0013189x018001032.

Buchanan, J., Pressick-Kilborn, K. and Maher, D. (2018). 'Promoting environmental education for primary school-aged students using digital technologies'. EURASIA Journal of Mathematics, Science and Technology Education 15 (2), p. 1661. https://doi.org/10.29333/ejmste/100639.

Buxton, C. A. (2006). 'Creating contextually authentic science in a "low-performing" urban elementary school'. Journal of Research in Science Teaching 43 (7), pp. 695-721. https: //doi .org/10.1002/tea. 20105.

Chen, J. and Cowie, B. (2013). 'Developing 'butterfly warriors': a case study of science for citizenship'. Research in Science Education 43 (6), pp. 2153-2177. https://doi.org/10.1007/s11165-013-9349-y.

Chinn, C. A. and Malhotra, B. A. (2002). 'Epistemologically authentic inquiry in schools: a theoretical framework for evaluating inquiry tasks'. Science Education 86 (2), pp. 175-218. https://doi.org/10.1002/sce.10001.

Condon, M. and Wichowsky, A. (2018). 'Developing citizen-scientists: effects of an inquiry-based science curriculum on STEM and civic engagement'. The Elementary School Journal 119 (2), pp. 196-222. https://doi.org/10.1086/700316.

Constantinou, C. P., Tsivitanidou, O. E. and Rybska, E. (2018). 'What is inquiry-based science teaching and learning?' In: Professional development for inquiry-based science teaching and learning. Ed. by O. Tsivitanidou, P. Gray, E. Rybska, L. Louca and P. C. Constantinou. Cham, Switzerland: Springer International Publishing, pp. 1-23. ISBN: 978-3-319-91406-0. https://doi.org/10.1007/978-3-319-91406-0_1.

Cornali, F., Pomatto, G. and Agnella, S. (2017). 'Deliberating science in Italian high school. The case of the Scienza Attiva project'. JCOM 16 (01), A02. https://doi.org/10.22323/2.16010202. 
Crall, A. W., Jarnevich, C. S., Young, N. E., Panke, B. J., Renz, M. and Stohlgren, T. J. (2015). 'Citizen science contributes to our knowledge of invasive plant species distributions'. Biological Invasions 17 (8), pp. 2415-2427.

https://doi.org/10.1007/s10530-015-0885-4.

De Pietro, O. (2013). 'Authentic and situated learning with the use of an adaptive search engine and a QR-code in mobile mode'. International Journal of Digital Literacy and Digital Competence 4 (3), pp. 19-30. https://doi.org/10.4018/ijdldc.2013070103.

Devisch, O. and Veestraeten, D. (2013). 'From sharing to experimenting: how mobile technologies are helping ordinary citizens regain their positions as scientists'. Journal of Urban Technology 20 (2), pp. 63-76. https://doi.org/10.1080/10630732.2013.769313.

Dickinson, J. L., Shirk, J., Bonter, D., Bonney, R., Crain, R. L., Martin, J., Phillips, T. and Purcell, K. (2012). 'The current state of citizen science as a tool for ecological research and public engagement'. Frontiers in Ecology and the Environment 10 (6), pp. 291-297. https://doi.org/10.1890/110236.

European Commission (2016). Open innovation, open science, open to the world a vision for Europe. Luxembourg: Publications Office of the European Union. https://doi.org/10.2777/061652.

Gadermaier, G., Dörler, D., Heigl, F., Mayr, S., Rüdisser, J., Brodschneider, R. and Marizzi, C. (2018). 'Peer-reviewed publishing of results from Citizen Science projects'. JCOM 17 (03), L01. https://doi .org/10.22323/2.17030101.

Gagné, R. (1977). The conditions of learning. 3rd ed. New York, NY, U.S.A.: Holt, Reinhart and Winston.

Gaydos, M. J. and Squire, K. D. (2012). 'Role playing games for scientific citizenship'. Cultural Studies of Science Education 7 (4), pp. 821-844. https://doi.org/10.1007/s11422-012-9414-2.

Gee, J. P. (2003). What video games have to teach us about learning and literacy. New York, NY, U.S.A.: Palgrave Macmillan.

Greenhow, C. and Lewin, C. (2016). 'Social media and education: reconceptualizing the boundaries of formal and informal learning'. Learning, Media and Technology 41 (1), pp. 6-30. https://doi .org/10.1080/17439884.2015.1064954.

Herodotou, C., Aristeidou, M., Sharples, M. and Scanlon, E. (2018). 'Designing citizen science tools for learning: lessons learnt from the iterative development of nQuire'. Research and Practice in Technology Enhanced Learning 13 (1), p. 4. https://doi.org/10.1186/s41039-018-0072-1.

Hollow, B., Roetman, P. E. J., Walter, M. and Daniels, C. B. (2015). 'Citizen science for policy development: the case of koala management in South Australia'. Environmental Science \& Policy 47, pp. 126-136. https://doi.org/10.1016/j.envsci.2014.10.007.

Huang, C. S., Yang, S. J., Chiang, T. H. and Su, A. Y. (2016). 'Effects of situated mobile learning approach on learning motivation and performance of EFL students'. Journal of Educational Technology \& Society 19 (1), pp. 263-276. URL: https://www . jstor.org/stable/jeductechsoci.19.1.263.

Jordan, R. C., Ballard, H. L. and Phillips, T. B. (2012). 'Key issues and new approaches for evaluating citizen-science learning outcomes'. Frontiers in Ecology and the Environment 10 (6), pp. 307-309.

https://doi.org/10.1890/110280. 
Kelemen-Finan, J., Scheuch, M. and Winter, S. (2018). ‘Contributions from citizen science to science education: an examination of a biodiversity citizen science project with schools in central Europe'. International Journal of Science Education 40 (17), pp. 2078-2098. https://doi.org/10.1080/09500693.2018.1520405.

Koomen, M. H., Rodriguez, E., Hoffman, A., Petersen, C. and Oberhauser, K. (2018). 'Authentic science with citizen science and student-driven science fair projects'. Science Education 102 (3), pp. 593-644. https://doi .org/10.1002/sce.21335.

Kountoupes, D. L. and Oberhauser, K. (2008). 'Citizen science and youth audiences: educational outcomes of the Monarch Larva Monitoring Project'. Journal of Community Engagement and Scholarship 1 (1), p. 5.

URL: http://jces.ua.edu/citizen-science-and-youth-audiences-educatio nal-outcomes-of-the-monarch-larva-monitoring-project/.

Kraiger, K., Ford, J. K. and Salas, E. (1993). 'Application of cognitive, skill-based and affective theories of learning outcomes to new methods of training evaluation'. Journal of Applied Psychology 78 (2), pp. 311-328. https://doi.org/10.1037/0021-9010.78.2.311.

Krathwohl, D. R., Anderson, L. W., Airasian, P. W., Cruikshank, K. A., Mayer, R. E., Pintrich, P. R., Raths, J. and Wittrock, M. C. (2002). A taxonomy for learning, teaching and assessing: a revision of Bloom's taxonomy of educational objectives. New York, NY, U.S.A.: Addison Wesley Longman.

Kullenberg, C. and Kasperowski, D. (2016). 'What is Citizen Science? A Scientometric Meta-Analysis'. Plos One 11 (1), e0147152. https://doi.org/10.1371/journal. pone.0147152.

Lave, J. and Wenger, E. (1991). Situated learning: legitimate peripheral participation. Cambridge, U.K.: Cambridge University Press.

Merlino, S., Locritani, M., Stroobant, M., Mioni, E. and Tosi, D. (2015). 'SeaCleaner: focusing citizen science and environment education on unraveling the marine litter problem'. Marine Technology Society Journal 49 (4), pp. 99-118. https://doi.org/10.4031/mtsj.49.4.3.

Monteiro, A., Silva, C. G., Brito, R. M. M. and Mota, P. G. (2014). Cell spotting vamos combater o cancro juntos. [in Portuguese]. URL: http://www . casadascienci as . org/cc/redindex . php? idart=303\&gid=39096749.

Monteiro, A., Silva, C. G. and Carrodeguas Villar, J. (2015). 'Cell spotting — let's fight cancer together!' Science in School 31, pp. 46-52.

URL: http://www. scienceinschool . org/content/cell-spotting- $\%$ E2\%80\%93let $\% 2 \% 80 \% 99$ s-fight-cancer-together.

Musavi, M., Friess, W. A., James, C. and Isherwood, J. C. (2018). 'Changing the face of STEM with stormwater research'. International Journal of STEM Education 5 (1), p. 2. https://doi .org/10.1186/s40594-018-0099-2.

National Research Council (NRC) (2012). A framework for K-12 science education: practices, crosscutting concepts and core ideas. Washington, DC, U.S.A.: National Academy Press. https://doi.org/10.17226/13165.

NGSS Lead States (2013). Next generation science standards: for states, by states. Washington, DC, U.S.A.: The National Academies Press. https://doi.org/10.17226/18290. 
Nikolopoulou, K. (2020). 'Secondary education teachers' perceptions of mobile phone and tablet use in classrooms: benefits, constraints and concerns'. Journal of Computers in Education 7 (2), pp. 257-275.

https://doi.org/10.1007/s40692-020-00156-7.

Orr, G. (April 2010). 'A review of literature in mobile learning: affordances and constraints'. In: $20106^{\text {th }}$ IEEE International Conference on Wireless, Mobile and Ubiquitous Technologies in Education. IEEE, pp. 107-111.

https://doi.org/10.1109/wmute.2010.20.

Peters-Burton, E. E. (2015). 'Outcomes of a self-regulated learning curriculum model'. Science E Education 24 (7-8), pp. 855-885. https://doi.org/10.1007/s11191-015-9769-3.

Phillips, T., Ferguson, M., Minarchek, M., Porticella, N. and Bonney, R. (2014). User's Guide for Evaluating Learning Outcomes in Citizen Science. Ithaca, NY, U.S.A.: Cornell Lab of Ornithology. URL: http://citizenscience org.

Pocock, M. J. O. and Evans, D. M. (2014). 'The success of the Horse-Chestnut Leaf-Miner, Cameraria ohridella, in the U.K. revealed with hypothesis-led citizen science'. PLoS ONE 9 (1), e86226. https://doi.org/10.1371/journal . pone.0086226.

Rocard, M., Csermely, P., Jorde, D., Lenzen, D., Walberg-Henriksson, H. and Hemmo, V. (2007). Science education now: a new pedagogy for the future of Europe. EU 22845. European Commission.

URL: https://ec. europa.eu/research/science-society/document_library /pdf_06/report-rocard-on-science-education_en.pdf.

Silva, C., Monteiro, A. J., Manahl, C., Lostal, E., Schäfer, T., Andrade, N., Brasileiro, F., Mota, P., Sanz, F. S., Carrodeguas, J. and Brito, R. (2016). ‘Cell spotting: educational and motivational outcomes of cell biology citizen science project in the classroom'. JCOM 15 (01), A02. https://doi.org/10.22323/2.15010202.

Skarlatidou, A., Ponti, M., Sprinks, J., Nold, C., Haklay, M. and Kanjo, E. (2019). 'User experience of digital technologies in citizen science'. JCOM 18 (01), E. https://doi.org/10.22323/2.18010501.

Toomey, A. H. and Domroese, M. C. (2013). 'Can citizen science lead to positive conservation attitudes and behaviors'. Human Ecology Review 20 (1), pp. 50-62. URL: https://www . jstor .org/stable/24707571.

Trumbull, D. J., Bonney, R., Bascom, D. and Cabral, A. (2000). 'Thinking scientifically during participation in a citizen-science project'. Science Education 84 (2), pp. 265-275. https: //doi .org/10.1002/ (SICI) 1098-237X (200003)84\%3 A2\%3C265\%3A\%3AAID-SCE7\%3E3. 0.CO\%3B2-5.

Wallace, D. E. and Bodzin, A. M. (2017). 'Developing scientific citizenship identity using mobile learning and authentic practice'. Electronic Journal of Science Education 21 (6), pp. 46-71. URL: http://ejse.southwestern.edu/article/view/17688.

Zárybnická, M., Sklenicka, P. and Tryjanowski, P. (2017). 'A webcast of bird nesting as a state-of-the-art citizen science'. PLOS Biology 15 (1), e2001132.

https://doi.org/10.1371/journal.pbio.2001132. 
Olia E. Tsivitanidou is a Research Associate at the EdMedia Research Group of the Research Centre on Interactive media, Smart systems, and Emerging Technologies (RISE). She holds a bachelor's degree in Primary School Teaching (2008), a MA in Learning in Natural Sciences (2010), a Ph.D. in Learning in Natural Sciences (2014), and a BSc in Physics (2020). Her research interests include Science Education, Science Communication, Inquiry-based Science Teaching and Learning, and Peer-Assessment processes in computer-supported learning environments. E-mail: o.tsivitanidou@rise.org.cy.

Andri Ioannou is an Associate Professor in the Department of Multimedia and Graphic Arts of the Cyprus University of Technology (CUT) and Director of the Cyprus Interaction Lab (CIL), an interdisciplinary research Lab dealing with topics in the intersection of Educational Technology and Human-Computer Interaction. Andri is also a Team Leader in the Research Centre on Interactive media, Smart systems, and Emerging technologies. Her research contributes to key areas of design and evaluation of technology-enhanced learning environments.

E-mail: andri.ioannou@gmail.com.

\section{How to cite}

Tsivitanidou, O. E. and Ioannou, A. (2020). 'Citizen Science, K-12 science education and use of technology: a synthesis of empirical research'. JCOM 19 (04), V01. https://doi.org/10.22323/2.19040901. 